\title{
The influence of ambidextrous organization and authentic followership on innovative perfor- mance: The mediating role of change readiness
}

\author{
Kosasih Kosasih $^{a^{*}}$, Wibowo ${ }^{b}$ and Saparuddin ${ }^{b}$
}

${ }^{a}$ Universitas Mercubuana, Indonesia

${ }^{b}$ Universitas Negeri Jakarta, Indonesia

CHRONICLE ABSTRACT

Article history:

Received: November 4, 2019

Received in revised format: No-

vember 292019

Accepted: December 12, 2019

Available online:

December 14, 2019

Keywords:

Change readiness

Ambidextrous organization

Authentic followership

Innovative performance

Innovation

\begin{abstract}
The purpose of this study is to examine the role of change readiness in mediating the effects of ambidextrous organization and authentic followership on innovative performance. The result of this study indicate that authentic followership, ambidextrous organization and change readiness directly influenced on innovative performance. The mediating role of change readiness did not significantly influence on relationship between authentic followership and innovative performance. Meanwhile, the mediating role of change readiness significantly influenced on the relationship between ambidextrous organization and innovative performance. The study emphasizes on the strength of the organization ambidexterity and authentic followership for successes of the innovative performance mediated by change readiness.
\end{abstract}

\section{Introduction}

Organizational change must be made so that firms can adapt to the changing business environment quickly and make strategic decisions that are suitable for organization (Ceiik \& Ozsoy, 2016), compete effectively, improve performance through quality improvement, minimize costs, and produce different products and services with other competitors (Ndahiro et al., 2015). Modern companies are required to produce innovations in order to improve company performance indicators (Peronja, 2015; Price et al., 2013) and be able to survive in a constricting competition (Shinwon et al., 2015). Many companies have difficulty in implementing organizational change (Mosadeghrad \& Ansarian, 2014), due to scale of change that is too large and sustainable, which has a negative impact on employee behavior (Elizabeth Viktorsson, 2014), and employee resistance that is not always shown authentically forthright (Robbins \& Judge, 2013). The main factor for the success of the change process is the readiness of the organization through emphasizing the importance of building a sense of urgency through cooperation between employees aggressively (Elizabeth Viktorsson, 2014), clarity of information to employees about changes made (Shinwon et al., 2015), employee initiatives (Sofat \& Kiran, 2015) and organizational structures that have clarity in the context of change (Benzer et al., 2017). Tai et al.'s (2017) research suggests companies to implement an ambidextrous organization in improving information and technology change capabilities. However, other studies have found that ambidexterity does not have a direct relationship with organizational performance (Susanto et al. , 2017; Mardhatillah et al., 2017).

This study aims to examine the effect of authentic followership, ambidextrous leadership and readiness for change on corporate innovation performance, and examine the role of readiness for change in the influence of authentic followership and ambidextrous organizations on innovative performance. Although previous studies have discussed the influence of authentic 
followership variables (de Zilwa, 2016; Leroy et al., 2015) and ambidextrous organizations (Bresciani et al., 2018; Popadić et al., 2016) on the performance of innovation, but none of them examined the role of mediating change readiness in the relationship between these variables.

\section{Literature Review}

Innovative performance can be described under various categories, viz. product productivity and the success of new products (Dul \& Ceylan. 2014), differentiated into radical innovative performance and incremental innovative performance (Forés \& Camisón, 2016), integrated measures of objective and subjective performance (Camisón \& Villar-López, 2014) as well as the ability to introduce new products and services to the market before competitors, the percentage of new products, new product and service projects, innovations introduced for work processes and methods, new product quality / series introduced, the number of innovations under the protection of wealth intellectual and administrative system renewal and mindset in line with the corporate environment (Tajasom et al., 2015). OECD divides innovative performance into 3 dimensions, viz. corporate system, organizational and external relations innovations (Camisón \& Villar-López, 2014). Curado et al. (2018) divide the dimensions of innovative performance into 2 (two) dimensions, namely: efficiency and accuracy. Whereas Ajayi, (2013) further identifies four dimensions of innovative change: product innovation, process innovation, position innovation, and paradigm innovation. Innovative performance can be measured from input (research capital stock and high skill staff) and output (number of product innovations and number of patents (Cruz-Cázares et al., 2013), using 6 items of innovative individual work behavior at the stage of innovation (idea making, idea promotion, and realization of ideas) from the innovative behavior of employees (Abbas \& Raja, 2015). Innovative performance can also be measured by market share innovation (Wadhwa et al., 2017), discovery of new products, devices and process systems (Tajasom et al., 2015). Meanwhile, Kilic et al. (2015) measure the size of innovative performance by taking into account the effects of innovation on company performance measured in indicators of production, finance and market performance. The concept of authentic followership began to emerge at the beginning of this century (de Zilwa, 2016). Authentic followers are defined as psychological capacity and a follower's conceptual framework (Kernis, 2003), with authentic leader (Shamir \& Eilam, 2005; Crawford et al., 2018), proactive and critically constructive (Zilwa, 2014).

Hannah (2011) adopted the dimensions compiled by Walumbwa et al. (2008), in measuring authentic followership by using characteristics of balanced processing, ethical standards, transparency, self-awareness, and openness. According to Kernis and Goldman, (2006) the dimensions of authentic followership are: awareness (motives, feelings, desires, strengths, weaknesses and emotions), unbiased processing (objectivity and acceptance), behavior (acting in a way with values, preferences \& needs) and relational orientation (value, openness, originality \& truth). Authentic as a follower is measured by the following dimensions: self-awareness, balanced processing, relational transparency and internalized moral perspective (Leroy et al., 2015). Based on the concepts above, in this study the researchers defined authentic followers as an authentic awareness and desire of an employee in the involvement of achieving organizational goals without coercion from the leader and carried out voluntarily with the following indicators: work awareness, behavior, openness and value. The organization's ambidexterity is a new topic in management research that has begun to develop very rapidly over the past 17 years (Hughes, 2018). Organization ambidexterity also starts to get much attention to be researched and developed. Among the studies that discussed organization ambidexterity were empirical studies (Nosella et al., 2012; Lavie et al., 2010; Turner et al., 2015). The culture of organization ambidexterity is a high-level construction consisting of organizational diversity and shared vision, and has an impact on contextual ambidexterity and consequently the results of new product innovations (Wang \& Rafiq, 2014). Organization ambidexterity is defined as the ability of an organization to simultaneously pursue continuous exploitative and exploratory innovations (Junni et al., 2013) for short and long term performance (Wang et al., 2012). Turner et al. (2015) defines organization ambidexterity as the ability of an organization to use and improve existing knowledge (exploitation) and on the other hand also create new knowledge (exploration). Whereas Fu et al. (2016) define organization ambidexterity as the ability of an organization to simultaneously explore and exploit internal and external resources to be adaptive to future market changes. So the essence of organizational ambidexterity is an illustration of the organization's ability to improve business maturity and ability to explore competitive advantage in new fields (O'Reilly \& Tushman, 2013).

Cao et al. (2009) categorize two dimensions of ambidexterity, namely: balance of ambidexterity (BD) and combined of ambidexterity (CD). BD emphasizes the relative level of exploitation and exploration, because excessive service on both sides will cause performance risks. The dimensions of ambidextrous organizational culture by Wang et al. (2012) are: organizational diversity \& shared vision.

Based on the concepts above, in this study the researchers define an ambidextrous organization as the ability of an organization to exploit and explore all available resources in the organization with its measuring indicators, namely: exploration capabilities and exploitation capabilities. The definition of change readiness is the extent to which psychological readiness and behavior of organizational members individually in carrying out organizational changes (Weiner et al., 2008) which are shown in the form of positive and proactive responses (Stevens, 2013) individually (Vakola, 2013). While the dimensions of change readiness according to Castañeda et al. (2012) are: community and organizational climate that facilitates change (the condition of society and organization), current attitudes and efforts towards prevention (awareness, values, efforts), commitment to change (needed and commitment to change), the capacity to implement change (relational capacity, efficacy, skills and knowledge). 
In this study change readiness is defined as the ability of the organization and its members to face a planned change process within the organization, so that the goals of change can be achieved in an effective and efficient manner according to measurement indicators, including: a work climate that encourages innovation, facilities and equipment innovation, awareness of change, commitment to change, knowledge of the process of improvement and ability to make improvements.

\section{Research Methodology and Framework}

Some studies conclude that followership influences innovation (Bufalino, 2018), as a mediator on organizational performance (Kim \& Schachter, 2015), produces innovative performance (Zacher \& Wilden, 2014), has a significant positive relationship with team performance (Spicer, 2018), and plays an important role in achieving organizational performance (Nejad et al., 2015). Authentic followership is positively related to performance using self-determination theory (Leroy et al., 2015) and has the potential to strengthen positive organizational culture so as to improve organizational performance (de Zilwa, 2016). Based on above researches, this study proposes the following hypothesis:

$\mathbf{H}_{1}$ : Authentic followership has a positive influence on innovative performance.

Ambidextrous organization is a solution to the achievement of the organizational resulting in different performance (Simsek, 2009) which has an effect on stronger performance in high capital companies (Fu et al., 2016). Organization ambidexterity plays an important role in improving company performance (Wang \& Rafiq, 2014) and has a significant relationship with the results of new product innovations. Technology exploration and exploitation activities complement and influence company performance (Zhang et al., 2017), have an impact on organizational performance (O'Reilly \& Tushman, 2013; Junni et al., 2013; Lubatkin et al., 2006; Sarkees et al., 2010; Junni et al., 2013; Popadić et al., 2016; Faisal Ahammad et al., 2015; Kauppila, 2010) and innovation (Bresciani et al., 2018). Based on above researches, our study proposes the following hypothesis:

$\mathbf{H}_{2}$ : Ambidextrous organization has a positive influence on innovative performance.

Organizational readiness for changes that support the development of innovations in products and processes can attain high company performance (Camisón \& Villar-López, 2014) and resulting the best corporate performance (Kilic et al., 2015). Organizational innovation strategies have a positive impact on innovative performance (Bolívar-Ramos et al., 2012). Employee readiness in facing changes in companies in organizations improves organizational performance (Ndahiro et al., 2015). Based on above researches, our study proposes the following hypothesis:

$\mathbf{H}_{3}$ : Readiness for change has a positive influence on innovative performance.

Based on several studies it was concluded that followership significantly moderated the relationship of leadership and employee participation in change (Khan et al., 2018), the need for changes that shape authentic behavior of employees will influence support for change (Abdel-Ghany, 2014), employees who are ensure in their abilities experience a high level of readiness to change (Vakola, 2014). Affective commitment of employees, which is characteristic of authentic followership also has to do with readiness for change (Soumyaja et al., 2015). Based on the above researches, our study proposes the following hypothesis:

H4: Authentic followership has a positive influence on change readiness.

Some studies conclude that there is a positive relationship between the ability of ambidexterity and preparation for changes in the company (Judge \& Blocker, 2008), exploration and exploitation have a positive influence on the ability of radical change and gradual change ability (Nazir et al., 2011), and exploration activities and exploitation in order to find the right way to respond to changes that occur (Franco \& Cerimele, 2019). Zhang et al. (2018) concluded that the preceding factors of the ability of ambidexterity had a positive influence on the ability and performance of employees in the process of change. Based on the above researches, our study proposes the following hypothesis:

Hs: Organization ambidexterity has a positive influence on readiness for change.

Some studies concluded that authentic followers have the potential to strengthen organization (de Zilwa, 2016), strengthens organizational capabilities (Jin et al., 2016), has a significant role in forming ambidexterity (Klonek et al., 2018). Based on the researches, our study proposes the following hypothesis:

H6: Authentic followership has a positive influence on an ambidextrous organization.

In addition to the hypotheses mentioned above, this study also examined the role of change readiness as a mediator with the following hypotheses:

$\mathbf{H}_{7}$ : Authentic followership has an influence on innovative performance by mediating change readiness. 
H8: Ambidextrous organization has an influence on innovative performance by mediating change readiness.

Based on our proposed hypotheses, the theoretical framework can be described in the model constellation as follows:

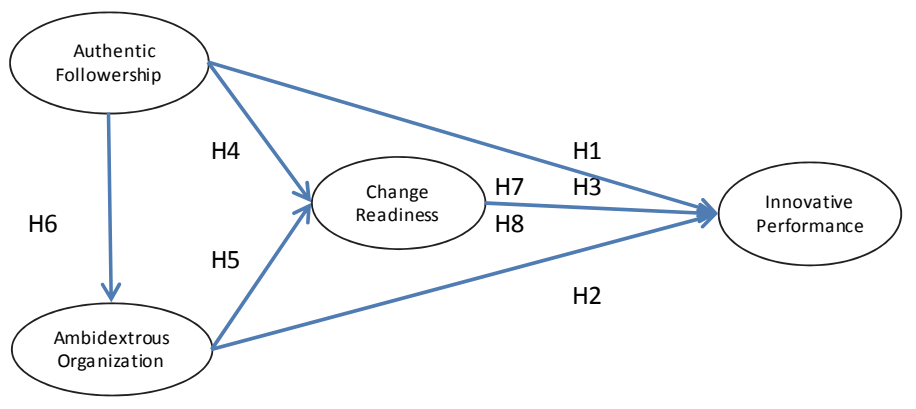

Fig. 1. Research Framework

The research was conducted in a manufacturing company located in Indonesia with a purposive sampling technique 223 employees with position team leader level up to director. The instrument test was conducted using SPSS 2.5 to test the validity where $\mathrm{r}($ table $)=0.361(\mathrm{~N}=30)$ and the reliability test with the Cronbach Alpha value $>0.60$. SEM model is tested using Lisrel 8.7 by the Confirmatory Factor Analysis (CFA) test and the model equation test.

\section{Result and Discussion}

\subsection{Validity Test}

The results of the validity test on the indicator questions from innovative performance variables (KI1, KI2, KI3, KI4, KI7, KI8, KI9 and KI10) found that the question KI1 was invalid ( $r<0.362)$, so it must be discarded. After item KI1 was removed and all indicators became valid $(\mathrm{r}>0.361)$. While the results of the validity test for indicators of authentic followership variables (AF1, AF2, AF3, AF4, AF5, AF6, AF7 and AF8), ambidextrous organizations (AO1, AO2, AO3, AO4, AO5, AO6, AO7, AO8, AO9 and AO10) and readiness for change (KP1, KP2, KP3, KP4, KP5, KP6, KP7, KP8, KP9 and KP10), were all valid $(\mathrm{r}>0.361)$.

\subsection{Reliability Test}

The reliability test results on innovative performance variable is a high level of reliability (Cronbach's alpha $=0.891$ ), authentic followership variable is a high level of reliability (Cronbach's alpha $=0.873$ ), ambidextrous organization variable is high level of reliability $($ Cronbach's alpha $=0.873)$ and change readiness variable is high reliability rate $($ Cronbach's alpha $=$ 0.888). Thus, it can be concluded that all indicators of variables are reliable.

\subsection{SEM Model Test Results}

The goodness of fit model test results is as the table below:

Table 1

Goodness of Fit

\begin{tabular}{cccc}
\hline Goodness-of-Fit & Cut-off-Value & Result & Description \\
\hline RMR & $\geq 0,05$ atau $\leq 0,1$ & 0.026 & Good Fit \\
RMSEA & $<0,08$ & 0.077 & Good Fit \\
AGFI & $\geq 0,90$ & 0.73 & Marginal Fit \\
NFI & $\geq 0,90$ & 0.96 & Good Fit \\
CFI & $\geq 0,90$ & 0.98 & Good Fit \\
\hline
\end{tabular}

All the criteria of goodness have a higher value than the minimum value, except for AGFI criteria. An AGFI goodness limit criteria is 0.90 , while the model has AGFI value of 0.73 or less difference 0.17 of limit criteria. However, since others criteria have been a good fit, it can be concluded that the model SEM formed already good fit model. 


\subsection{SEM Model Equation}

The equation of the SEM model on the correlation of each variable to innovative performance is as follows: Innovative performance $=0.43$ change readiness +0.47 authentic followership +0.088 ambidextrous organization. While the indirect correlation of each variable due to the mediation of change readiness is as follows: Innovative performance $=0.67$ authentic followership +0.13 ambidextrous organizations.

\subsection{Hypothesis testing}

Testing hypotheses for each hypothesis can be seen in the following table:

Table 2

Hypothesis Test

\begin{tabular}{|c|c|c|c|c|}
\hline & Hypothesis & t-calc & Result & Description \\
\hline H1 & $\begin{array}{l}\text { Authentic followership significantly } \\
\text { influences the innovative perfor- } \\
\text { mance. }\end{array}$ & 7.64 & Ha accepted & $\begin{array}{l}\text { Authentic followership signifi- } \\
\text { cantly influences the innovative } \\
\text { performance. }\end{array}$ \\
\hline $\mathrm{H} 2$ & $\begin{array}{l}\text { Ambidextrous organization signifi- } \\
\text { cantly influences on the innovative } \\
\text { performance. }\end{array}$ & 4.52 & Ha accepted & $\begin{array}{l}\text { Ambidextrous organization sig- } \\
\text { nificantly influences on the inno- } \\
\text { vative performance. }\end{array}$ \\
\hline $\mathrm{H} 3$ & $\begin{array}{c}\text { Change readiness significantly in- } \\
\text { fluences on the innovative perfor- } \\
\text { mance. }\end{array}$ & 3.05 & Ha accepted & $\begin{array}{l}\text { Change readiness significantly in- } \\
\text { fluences on the innovative perfor- } \\
\text { mance. }\end{array}$ \\
\hline $\mathrm{H} 4$ & $\begin{array}{l}\text { Authentic followership significantly } \\
\text { influences on the change readiness. }\end{array}$ & 5.93 & Ha accepted & $\begin{array}{l}\text { Authentic followership signifi- } \\
\text { cantly influences on the change } \\
\text { readiness. }\end{array}$ \\
\hline H5 & $\begin{array}{l}\text { Ambidextrous organization signifi- } \\
\text { cantly influences on the change } \\
\text { readiness. }\end{array}$ & 7.25 & Ha accepted & $\begin{array}{l}\text { Ambidextrous organization sig- } \\
\text { nificantly influences on the } \\
\text { change readiness. }\end{array}$ \\
\hline H6 & $\begin{array}{l}\text { Authentic followership significantly } \\
\text { influences on the ambidextrous or- } \\
\text { ganization. }\end{array}$ & 19.15 & Ha accepted & $\begin{array}{l}\text { Authentic followership signifi- } \\
\text { cantly influences on the ambidex- } \\
\text { trous organization. }\end{array}$ \\
\hline $\mathrm{H} 7$ & $\begin{array}{c}\text { Change readiness mediating signifi- } \\
\text { cantly influences the authentic fol- } \\
\text { lowership on innovative perfor- } \\
\text { mance. }\end{array}$ & 0.85 & $\begin{array}{l}\mathrm{Ha} \\
\text { rejected }\end{array}$ & $\begin{array}{l}\text { Change readiness has not mediat- } \\
\text { ing significantly influences the } \\
\text { authentic followership on innova- } \\
\text { tive performance. }\end{array}$ \\
\hline $\mathrm{H} 8$ & $\begin{array}{c}\text { Change readiness mediating signifi- } \\
\text { cantly influences of ambidextrous } \\
\text { organization on innovative perfor- } \\
\text { mance. }\end{array}$ & 3.80 & Ha accepted & $\begin{array}{l}\text { Change readiness mediating sig- } \\
\text { nificantly influences of ambidex- } \\
\text { trous organization on innovative } \\
\text { performance. }\end{array}$ \\
\hline
\end{tabular}

\section{Conclusion and Recommendation}

This research has concluded that authentic followership, ambidextrous organization and change readiness directly influenced on innovative performance. Authentic followership and ambidextrous organization have indicated to have direct influence on change readiness. Authentic followership was proved to have direct influence on ambidextrous organization. The mediating role of change readiness did not have any meaningful effect on the context of influence of authentic followership on innovative performance. Meanwhile, the mediating role of change readiness significantly influenced on the context of the influence of ambidextrous organization on innovative performance. Based on the result of this research, the authors recommend the management to consider the strategy in improving innovative performance by enhancing the authentic followership of the employee, increasing the employee awareness upon the importance of organizational change and improving the organization's capability in exploiting current business process and explore a new business.

\section{References}

Abbas, M., \& Raja, U. (2015). Impact of psychological capital on innovative performance and job stress. Canadian Journal of Administrative Sciences/Revue Canadienne des Sciences de l'Administration, 32(2), 128-138.

Abdel-Ghany, M. M. M. (2014). Readiness for change, change beliefs and resistance to change of extension personnel in the New Valley Governorate about mobile extension. Annals of Agricultural Sciences, 59(2), 297-303.

Ajayi, O. M. (2013). The impact of employee ambidexterity on organisational and marketing innovations: organisational 
context for exploiting the present and exploring for the future (Doctoral dissertation, (C) OM Ajayi).

Benzer, J. K., Charns, M. P., Hamdan, S., \& Afable, M. (2017). The role of organizational structure in readiness for change: A conceptual integration. Health Services Management Research, 30(1), 34-46.

Bolívar-Ramos, M. T., García-Morales, V. J., \& García-Sánchez, E. (2012). Technological distinctive competencies and organizational learning: Effects on organizational innovation to improve firm performance. Journal of Engineering and Technology Management - JET-M, 29(3), 331-337.

Bresciani, S., Ferraris, A., \& Del Giudice, M. (2018). The management of organizational ambidexterity through alliances in a new context of analysis: Internet of Things (IoT) smart city projects. Technological Forecasting and Social Change, $136,331-338$.

Bufalino, G. (2018). Followership under the spotlight: implications for followership development. Industrial and Commercial Training, 50(2), 55-60.

Camisón, C., \& Villar-López, A. (2014). Organizational innovation as an enabler of technological innovation capabilities and firm performance. Journal of Business Research, 67(1), 2891-2902.

Cao, Q., Gedajlovic, E., \& Zhang, H. (2009). Unpacking organizational ambidexterity: Dimensions, contingencies, and synergistic effects. Organization Science, 20(4), 781-796.

Castañeda, S. F., Holscher, J., Mumman, M. K., Salgado, H., Keir, K. B., Foster-Fishman, P. G., \& Talavera, G. A. (2012). Dimensions of community and organizational readiness for change. Progress in Community Health Partnerships: Research, Education, and Action, 6(2), 219-226.

Ceiik, A., \& Ozsoy, N. (2016). Organizational change: Where have we come from and where are we going? International Journal of Academic Research in Accounting, Finance and Management Sciences, 6(1), 134-141.

Crawford, J., Dawkins, S., Martin, A., \& Lewis, G. (2018). Conceptualising Authentic Followers and Developing a Future Research Agenda. Authentic Leadership and Followership. https://doi.org/10.1007/978-3-319-65307-5_11

Cruz-Cázares, C., Bayona-Sáez, C., \& García-Marco, T. (2013). You can’t manage right what you can’t measure well: Technological innovation efficiency. Research Policy, 42(6-7), 1239-1250.

Curado, C., Muñoz-Pascual, L., \& Galende, J. (2018). Antecedents to innovation performance in SMEs: A mixed methods approach. Journal of Business Research, 89(June 2017), 206-215.

de Zilwa, D. (2016). The strengths and capacities of Authentic Followership. Leadership \& Organization Development Journal, 37(3), 310-324.

Dul, J., \& Ceylan, C. (2014). The impact of a creativity-supporting work environment on a firm's product innovation performance. Journal of Product Innovation Management, 31(6), 1254-1267.

Elizabeth Viktorsson, M. (2014). Why change implementation failed in a continuously changing organization. A case study of a governmental organization. Retrieved from $h$ ttp://www.diva-portal.se/smash/get/diva2:736619/FULLTEXT01.pdf

Faisal Ahammad, M., Mook Lee, S., Malul, M., \& Shoham, A. (2015). Behavioral ambidexterity: The impact of incentive schemes on productivity, motivation, and performance of employees in commercial banks. Human Resource Management, 54(S1), s45-s62.

Forés, B., \& Camisón, C. (2016). Does incremental and radical innovation performance depend on different types of knowledge accumulation capabilities and organizational size? Journal of Business Research, 69(2), 831-848.

Franco, M., \& Cerimele, A. (2019). Ambidexterity : a possible balance to manage complexity. Management (open-access), 2, 4-15.

Fu, N., Flood, P. C., \& Morris, T. (2016). Organizational ambidexterity and professional firm performance: the moderating role of organizational capital. Journal of Professions and Organization, 3(1), 1-16.

Gardner, W. L., Avolio, B. J., Luthans, F., May, D. R., \& Walumbwa, F. (2005). "Can you see the real me?” A self-based model of authentic leader and follower development. The Leadership Quarterly, 16(3), 343-372.

Hannah, S. T., Walumbwa, F. O., \& Fry, L. W. (2011). Leadership in action teams team leader and memebers'authenticity, Personnel Psychology, 64(3), 771-802.

Hughes, M. (2018). Organisational ambidexterity and firm performance: burning research questions for marketing scholars. Journal of Marketing Management, 34(1-2), 178-229.

Jin, M., McDonald, B., \& Park, J. (2016). Followership and job satisfaction in the public sector: The moderating role of perceived supervisor support and performance-oriented culture. International Journal of Public Sector Management, 29(3), 218-237.

Judge, W. Q., \& Blocker, C. P. (2008). Organizational capacity for change and strategic ambidexterity: Flying the plane while rewiring it. European Journal of Marketing, 42(9/10), 915-926.

Junni, P., Sarala, R. M., Taras, V. A. S., \& Tarba, S. Y. (2013). Organizational Ambidexteruty And Performance: University of North Carolina at Greensboro University of North Carolina at Greensboro. The Academy of Management Perspectives, 27(4), 299-312.

Kauppila, O. P. (2010). Creating ambidexterity by integrating and balancing structurally separate interorganizational partnerships. Strategic Organization, 8(4), 283-312.

Kernis, M. H. (2003). Toward a conceptualization of optimal self-esteem. Psychological inquiry, 14(1), 1-26.

Kernis, M. H., \& Goldman, B. M. (2006). A multicomponent conceptualization of authenticity: Theory and research. $A d-$ vances in Experimental Social Psychology, 38, 283-357.

Khan, S. N., Busari, A. H., Abdullah, S. M., \& Mughal, Y. H. (2018). Followership moderation between the relationship of transactional leadership style and employees reactions towards organizational change. Polish Journal of Management 
Studies, 17(1), 131-143.

Kilic, K., Ulusoy, G., Gunday, G., \& Alpkan, L. (2015). Innovativeness, operations priorities and corporate performance: An analysis based on a taxonomy of innovativeness. Journal of Engineering and Technology Management - JET-M, 35, 115133.

Kim, C., \& Schachter, H. L. (2015). Exploring followership in a public setting: Is it a missing link between participative leadership and organizational performance? American Review of Public Administration, 45(4), 436-457.

Klonek, F., Gerpott, F. H., \& Parker, S. K. (2018). Introducing a process-focused measurement application to capture temporal behavioural dynamics of leader-follower ambidexterity Introducing a process-focused measurement application to capture temporal behavioural dynamics of leader-follower ambidexterity Florian Klonek, University of Western Australia Fabiola H . Gerpott, Vrije Universiteit Amsterdam Sharon K. Parker, University of Western Australia Word Count: 990, (May).

Lavie, D., Stettner, U., \& Tushman, M. L. (2010). Exploration and exploitation within and across organizations. The Academy of Management Annals, 4(1), 109-155.

Leroy, H., Anseel, F., Gardner, W. L., \& Sels, L. (2015). Authentic leadership, authentic followership, basic need satisfaction, and work role performance: A cross-level study. Journal of Management, 41(6), 1677-1697.

Lubatkin, M. H., Simsek, Z., Ling, Y., \& Veiga, J. F. (2006). Ambidexterity and performance in small-to medium-sized firms: The pivotal role of top management team behavioral integration. Journal of Management, 32(5), 646-672.

Mardhatillah, A., Rahman, S., A., \& Ismail, K., (2017). The Relationship Between Psychosocial Predictors and Employee Readiness to Change. International Journal of Economics and Management, 11, 345-364.

Mosadeghrad, A. M., \& Ansarian, M. (2014). Why do organisational change programmes fail? International Journal of Strategic Change Management, 5(3), 189.

Nazir, S., \& Pinsonneault, A. (2011). The Effect of Application Ambidexterity on Firm Agility. In AMCIS.

Ndahiro, S., Shukla, J., \& Oduor, J. (2015). Effect of change management on the performance of government institutions in Rwanda: A case of Rwanda revenue authority. International journal of business and management review, 3(5), 94-107.

Nejad, M. A., Naami, A., \& Beshlideh, K. (2015). Followership Styles: The Difference of Employees in Their Job Motivation and Job Performance. Director-in-Chief: Reza Zamani, PhD, Associate Professor, Tehran University, 9(1), 24.

Nosella, A., Cantarello, S., \& Filippini, R. (2012). The intellectual structure of organizational ambidexterity: A bibliographic investigation into the state of the art. Strategic Organization, 10(4), 450-465.

O'Reilly, C. A., \& Tushman, M. (2013). Organizational Ambidexterity: Past, Present and Future. SSRN. https://doi.org/10.2139/ssrn.2285704

O’Reilly III, C. A., \& Tushman, M. L. (2008). Ambidexterity as a dynamic capability: Resolving the innovator's dilemma. Research in Organizational Behavior, 28, 185-206.

Peronja, I. (2015). Performance effects of the business process change in large enterprises: The case of Croatia. Management Journal of Contemporary Management Issues, 20(1), 1-22.

Popadić, M., Černe, M., \& Černe, M. (2016). Exploratory and exploitative innovation: The moderating role of partner geographic diversity. Economic Research-Ekonomska Istrazivanja , 29(1), 1165-1181.

Price, D. P., Stoica, M., \& Boncella, R. J. (2013). The relationship between innovation, knowledge, and performance in family and non-family firms: an analysis of SMEs. Journal of innovation and Entrepreneurship, 2(1), 14.

Robbins, S., \& Judge, T. A. (2013). Organizational Behavior 15th ed. Zhurnal Eksperimental'noi i Teoreticheskoi Fiziki. https://doi.org/10.12737/4477

Sarkees, M., Hulland, J., \& Prescott, J. (2010). Ambidextrous organizations and firm performance: The role of marketing function implementation. Journal of Strategic Marketing, 18(2), 165-184.

Shamir, B., \& Eilam, G. (2005). bWhat's your story? Q: A life-stories approach to authentic leadership development. The Leadership Quarterly, 16(3), 395-417.

Shinwon, S., Sunguk, P., Mihyun, G., Namgyu, K., \& Sunguk, L. (2015). Key Factors of Change Readiness for the Success of Management Innovation in Manufacturing Industry. International Journal of U-and e-Service, Science and Technology, 8(10), 179-192.

Simsek, Z. (2009). Organizational ambidexterity: Towards a multilevel understanding. Journal of management studies, 46(4), 597-624.

Simsek, Z., Heavey, C., Veiga, J. F., \& Souder, D. (2009). A typology for aligning organizational ambidexterity's conceptualizations, antecedents, and outcomes. Journal of Management Studies, 46(5), 864-894.

Sofat, K., \& Kiran, R. (2015). Management of Organizational Change and its Impact on Commitment : A Study of Select Indian IT Companies. Global Business and Management Research: In International Journal, 7(3), 69-87.

Soumyaja, D., Kamlanabhan, T. J., \& Bhattacharyya, S. (2015). Antecedents of Employee Readiness for Change : Mediating Effect of Commitment to Change. Management Studies and Economic Systems, 2(1), 11-25.

Spicer, J. W. (2018). Analysis of the Relationship Between a Supervisors' Leadership and Followership Styles and Team Performance Within a Knowledge Worker Environment (Doctoral dissertation, Northcentral University).

Stevens, G. W. (2013). Toward a process-based approach of conceptualizing change readiness. Journal of Applied Behavioral Science, 49(3), 333-360.

Susanto, F., Arafah, W., \& Husin, Z. (2017). Ambidextrous sustainability and manufacturing industry performance : The role of potential Non, PJMS, 16(2), 278-289. h

Tai, J. C. F., Wang, E. T. G., \& Wang, K. (2017). Investigating the Impact of IT Ambidexterity on Digital Innovation Capability. In Pacific Asia Conference on Information Systems. 
Tajasom, A., Hung, D. K. M., Nikbin, D., \& Hyun, S. S. (2015). The role of transformational leadership in innovation performance of Malaysian SMEs. Asian Journal of Technology Innovation, 23(2), 172-188.

Turner, N., Maylor, H., \& Swart, J. (2015). Ambidexterity in projects: An intellectual capital perspective. International Journal of Project Management, 33(1), 177-188.

Vakola, M. (2013). Multilevel Readiness to Organizational Change: A Conceptual Approach Multilevel Readiness to Organizational Change : A Conceptual Approach, (April), 37-41.

Vakola, M. (2014). What's in there for me? Individual readiness to change and the perceived impact of organizational change. Leadership and Organization Development Journal, 35(3), 195-209.

Wadhwa, A., Bodas Freitas, I. M., \& Sarkar, M. B. (2017). The paradox of openness and value protection strategies: effect of extramural R\&D on innovative performance. Organization Science, 28(5), 873-893.

Walumbwa, F. O., Avolio, B. J., Gardner, W. L., Wernsing, T. S., \& Peterson, S. J. (2008). Authentic leadership: Development and validation of a theory-based measure. Journal of management, 34(1), 89-126.

Wang, C. L., \& Rafiq, M. (2014). Ambidextrous organizational culture, contextual ambidexterity and new product innovation: A comparative study of UK and Chinese high-tech firms. British Journal of Management, 25(1), 58-76.

Wang, Z., Huang, J., \& Tan, B. (2012). Managing Organizational Identity Through Ambidextrous Capabilities: A Dual Level Analysis. PACIS 2012 Proceedings.

Weiner, B. J., Amick, H., \& Lee, S. Y. D. (2008). Conceptualization and measurement of organizational readiness for change: a review of the literature in health services research and other fields. Medical care research and review, 65(4), 379-436.

Zacher, H., \& Wilden, R. G. (2014). A daily diary study on ambidextrous leadership and self reported employee innovation. Journal of Occupational and Organizational Psychology, 87(4), 813-820.

Zhang, F., Wang, Y., Li, D., \& Cui, V. (2017). Configurations of innovations across domains: an organizational ambidexterity view. Journal of Product Innovation Management, 34(6), 821-841.

Zhang, Y. I., Wei, F., \& Constance, V. A. N. H. (2018). Individual Ambidexteiry And Antecedents In A Changing page proof AQ : Please, (August). https://doi.org/10.1142/S136391961950021X

de Zilwa, D., Lapierre, L., \& Carsten, M. (2014). A new conceptual framework for authentic followership. Followership: What is it, and why do people follow, 47-72.

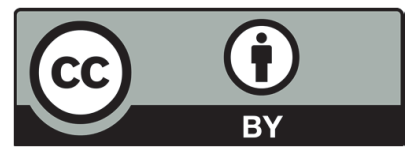

(C) 2020 by the authors; licensee Growing Science, Canada. This is an open access article distributed under the terms and conditions of the Creative Commons Attribution (CC-BY) license (http://creativecommons.org/licenses/by/4.0/). 